\title{
Cosmos and Republic: A Hidden Dialogue between Hannah Arendt and Alexander von Humboldt
}

\author{
Wolfgang Heuer \\ Privatdozent, Otto Suhr Institute for Political Science, Free University Berlin \\ Managing Editor of HannahArendt.net \\ Address: Ihnestraße, 21, Berlin, Germany 14195 \\ E-mail: wolfgang.heuer@gmx.de
}

\begin{abstract}
This text brings together two ideas, those of Hannah Arendt's republicanism and Alexander von Humboldt's cosmopolitanism. Both ways of thinking are seen as alternatives to a republican-biocentric perspective to the current problematic areas of the political and ecological crises. Arendt's critique of the modern natural sciences and the associated alienation from the earth, which still characterizes the current relationship to nature today, will be presented first. This critique is closely related to Arendt's thesis of world loss, i.e., the loss of the interpersonal pluralistic sphere. As an alternative to both forms of loss, Arendt develops the concept of an independent sphere of the political based on inter-personality, harmony with nature, and dialogical and consensual politics. While Arendt approaches nature from Kant's definition of self- and world-relationship and from her own definition of sustainable politics, Humboldt goes the opposite way, that is, from respecting nature as an independent organism to a republican understanding of politics that, like Arendt, rejects the exploitation of humans as well as nature. Arendt and Humboldt both belong to the tradition of the Enlightenment that (in addition to phenomenology, self-reflection, the values of human dignity and human rights, and the unity of understanding and feeling) also includes a cosmopolitanism and freedom of movement for acting and judging citizens.
\end{abstract}

Keywords: Arendt, Humboldt, republicanism, cosmos, Anthropocene, nature, process, cosmopolitanism

(c) Heuer W., 2019

(C) Centre for Fundamental Sociology, 2019

Voices from outer space:

Soichi Noguchi: "We are citizens of outer space."

Juri Gagarin: "I saw how beautiful our planet is. People, let's preserve and multiply this beauty, not destroy it!"

Nicole Stott, on behalf of 18 astronauts to the delegates of the Paris Climate Conference 2015: "The one thing we all wish is that groups like yours could be holding your meeting in space with the beautiful horizon to horizon view of our planet as a backdrop. It would be an aweinspiring distraction for sure, but there would be nothing better for reinforcing the significance of what you're doing there today." 
The location of these astronauts is not the Archimedean point from which, according to Arendt, cosmic extraterrestrial energy in the form of nuclear energy is directed towards the Earth $(1958,2006 \mathrm{~b})$. On the contrary, it is the physical location of a sensual view of our planet whose limitedness, togetherness, and beauty is rendered visible. The earth appears as a terrestrial globe, but at the same time, as a world in Arendt's sense as she meant it, as a space of interpersonal relationships, or at least as a potential space, or as a potential world. We know Arendt's illuminating account of the human conditionality of plurality and freedom. According to Arendt, plurality presupposes both equality and diversity (1958: 35-37), whereas freedom is both action and responsibility (1987). This account merely describes the possibility of its full potential. The real and at the same time imaginary view of the earth from this location reveals a constant struggle in ordinary everyday life between the realization of plurality, freedom, and responsibility on the one hand, and the pursuit of hegemony, sovereignty, and the oppression and destruction of worldly spaces on the other. The common world is rife with conflict zones. Not only are they caused by failed states and hegemonic powers, they are even encouraged by the fact that the world itself is a kind of failed community in which even a shared, but largelypowerless instrument like the "United Nations" has little directive force.

With the emergence of discussions about the Anthropocene, it is no longer only a question of defending human plurality, but also of the natural foundations of life, those of earth, water, air, climate, and living beings, i.e., the preservation of the earth (or in the jargon of Christian peace and environmental initiatives of the 1980s, the preservation of creation). To make the world in such a way presupposes an alternative; are we to approach the problems of the world and our relationship to creation with a liberal and instrumental way of thinking and acting, or do we want to regard plurality, politics, the world and nature/earth not as a means to an end, but as an end in itself: in other words, with a cosmopolitan, republican attitude?

This question prompts me to bring together two research directions that have a critical relationship to modernity; Hannah Arendt's republicanism, on the one hand, and the exploration of nature by the Enlightenment naturalist Alexander von Humboldt, whom Andrea Wulf called the "inventor of nature" (2016), on the other. Both are critics of a utilitarian understanding of politics and nature, both are phenomenologists, both are intellectuals in the tradition of the European Enlightenment, and both are republicans. This essay intends to contribute to a deepening of the initial considerations in this direction (Cannavò, 2016).

Before creating a kind of republican-biocentric-philosophy opposing the anthropocentric way of thinking, a brief encounter with Arendt and Humboldt may point to yet another way of thinking that would combine Arendt's and Humboldt's world-views that are mutually enriching. As a result, Arendt's idea of strong republican citizenship would elevate the ecological rationality of citizens in their relationship with nature to a decisive level, while Humboldt's understanding of nature would radicalize these relationships with the assumption of a worldwide unity of man and nature. 
In the following, I would first like to address Arendt's critique of the modern understanding of nature as one of the foundations of her republican understanding, and ask about the indispensability of strong republican thinking for the preservation of the earth, i.e., political thinking carried by sustainability and civic commitment. I will then ask whether Humboldt's views on nature and the cosmos offer an understanding of nature in tune with republicanism. Finally, I will ask about Arendt and Humboldt's methods and ways of thinking that correspond to republicanism and the cosmos.

\section{Arendt — Nature as a Process}

In the following section, I will highlight two aspects of Arendt's analysis of nature; her critique of the alienation of the earth and the world by the natural sciences, and her critique of the understanding of nature as a process.

The secondary literature on Arendt's idea of nature rarely deals with the relationship between ecology and politics, with the exception of publications by Hargis (2016) and Whiteside (1998). They emphasize the strong link between the concepts of culture and nature, which Arendt sees as far more interconnected than her strict discrimination of terms suggests, namely on the issue of the cultural preservation of nature. The other studies deal with some particular aspects of Arendt's work (Chapman, 2007; Ott, 2009; Donohoe, 2017; Yaqoob, 2014).

Referring to the alienation of the earth and of the world, Arendt describes modern discoveries and inventions not as liberating and enriching progress, but as the alienation from the earth through acceleration, as a reduction of distance on earth through distance from earth and, at the same time, as a worldlessness due to the dual movement of expropriation and the process of accumulation. According to Arendt, "the Renaissance's new-wakened love for the earth and the world" (1958: 240) as a response to the rationalism of medieval scholasticism became the first victim of the new science. The latter went beyond the heliocentric view of the world in an effort to move around the universe with a panoramic relativism rather than a center and to conduct experiments with cosmic processes of evolution "unknown in the household of nature ... at the risk of endangering the natural life process" (Ibid.: 238) that can extinguish all life.

The complicated relation to nature did not first emerge with the capture of the Archimedean point; it was originally created with a modern natural science that does not deal with nature per se or with its own questions; subordinating facts to laws can prove everything. Arendt wrote that Man is reduced to "no more than a special case of organic life, ... to whom man's habitat - the earth, together with earthbound laws - is no more than a special borderline case of absolute, universal laws" (2006b: 260). Sensory perceptions, common sense, and language are replaced by constructs and formulas. Arendt quotes Nils Bohr as saying that the aim is no longer "to augment and order" (261) human experience, but to discover what lies behind natural phenomena.

It is striking that Arendt considers world alienation not merely as a scientific process, but as a broad cultural process in which the natural sciences determine the prevailing 
views in religion, philosophy, historiography, and political theory. Hence, she asserts "the almost too precise congruity of modern man's world alienation with the subjectivism of modern philosophy" (1958: 248) - from the doubts of Descartes, through Hobbes and English sensualism, empiricism, and pragmatism to the existentialism and positivism of the twentieth century - accompanied by the withdrawal of people into their own selves. It was therefore not simply ideas about alienation from the world that moved philosophers, but concrete events, inventions, and discoveries to which they responded with doubts, axiomatic conclusions, and a "catastrophic loss of judgement."

The second aspect, the interpretation of nature as a process, according to Arendt, comes out as a result of technical progress. The interpretation of history was likewise affected by thinking in processes. Nature and history were both subjected to the flow of progress (2002: XX, 8), so that the procedural nature of examining them is inevitably constructed "in the sense of the consuming process of life that is most immediately given to our experience" (XXII, 3). This life process corresponds to Arendt's characterization of work in its processual, "destructive, devouring aspect of the laboring activity ... visible only from the standpoint of the world" (1958: 87). Arendt, as a phenomenologist, is particularly disturbed by the phenomenon (or anything particular) that no longer appears "in the sense of an aspect or an example. It no longer shows itself at all, but is constantly consumed, 'proceeded"' (2002: XXII, 3). Finally, Arendt observes that progress in science and technology only came about because human beings intervened in interpersonal areas in a way that was previously confined to the realm of history. Scientific and technical rather than political actors develop potential extermination processes, and today intervene in nature on a large scale with breeding, with genetic changes (1994b: 77).

According to Arendt, the difference between the ancient and the modern idea of nature could not be any greater. On the one hand, the immortality of nature and human deeds in ancient Greece, "which would deserve to be and, at least to a degree, are at home with everlastingness, so that through them mortals could find their place in a cosmos where everything is immortal except themselves" (1958: 19). On the other hand, there is the "world of things, which we already produce as transient, as parts of a gigantic production and consumption process, which makes them emerge and disappear ever faster" and which "is itself surrounded by a transient nature, the disappearance of which takes place only at a slower pace - and this only as long as man leaves the natural processes of the emergence and disappearance of seas, continents and mountains to himself and does not intervene in an accelerating way. Immortality, in any case, has disappeared from the world surrounding human beings as well as from the nature surrounding the world. On its part, it is surrounded by a transient nature, the disappearance of which takes place only at a slower pace - and this only as long as human beings leave the natural processes

1. This phrase only exists in the German version authorized by Arendt when she wrote: “. . die Verachtung der deutschen idealistischen Philosophie für den gesunden Menschenverstand hängt aufs engste mit Hegels ausdrücklicher Verachtung für die von Kant so gepriesene menschliche Urteilskraft, das eigentlich höchste Vermögen der Vernunft, zusammen" "'The contempt of German idealistic philosophy for common sense is closely linked to Hegel's explicit contempt for the human power of judgement so praised by Kant, which is in fact the intellect's highest asset") (1994b: 68). 
of the origin and disappearance of seas, continents and mountains to themselves and do not intervene in an accelerating way. Immortality, in any case, has disappeared from the world surrounding man as well as from the nature surrounding the world" (1994b: 76f). ${ }^{2}$

These procedural interventions have assumed the character of irreversible actions, comparable to interpersonal actions (2006a: 86-90). Over time, the transience of the world of things and of nature (1994b: 72, 77) due to processes and interventions in the world and in nature, leads to consequences which are irreversible (77f.). In this process, the ability to act has become more and more the "exclusive prerogative" of natural scientists. She continues by saying that "It seems only proper, that their deeds should eventually have turned out to have greater news value, to be of greater political significance than the administrative and diplomatic doings of most so-called statesmen" (1958: 206).

Arendt's critiques of the loss of the earth and of the world and of the process of thinking, of the endangerment of man and nature, and of the quasi-unrestricted actions of scientists remain topical even in the face of newer technological developments of digitalization, biotechnology, and AI. At the same time, the exploitation, pollution, and destruction of the living environment is gaining momentum.

In Arendt's view, this process threatens to destroy man's stature unless reason, public spirit, and the ability to judge take center stage again. The aim is to reverse the emancipation of the natural sciences from the "anthropocentric, i.e., truly humanistic, concerns" (2006b: 260) that were not explained in detail, but in a political rather than a conservative or romantic way. She ends her essays on "Nature and History" (in the German version) with the remark that she could or should not offer solutions in such an essay, but "perhaps contribute something to self-declaration and above all encourage to pursue the essence and the possibilities of action ..." (1994b: 79); in other words, political action in the context of republicanism. Thus Arendt defends the freedom and curiosity of research, but at the same time considers "the layman and the humanist" indispensable in order "to judge what the scientist is doing because it concerns all men, and this debate must of course be joined by the scientists themselves insofar as they are fellow citizens" (2006b: 262). It should, however, be noted that humanism today is no longer an anthropocentric, but a biocentric understanding of the world.

I would like to add a third aspect, that of the role of nature in relation to the human necessities of life. Arendt touches on it only briefly with regard to the role of essential reproductive food, metabolism, and life as the basic condition of working. Yet, Arendt contemplates the beauty and indispensability of nature. Thus, when she turns to the world of phenomena, which not only constitutes the space of the political but according to the biologist Portmann as cited by Arendt in agreement, is also characteristic of all sentient

2. See Arendt, 1994b: $76 f .:$ "Die Welt der Dinge, die wir schon als vergängliche herstellen, als Teile eines gigantischen Produktions- und Konsumtionsprozesses, der sie immer schneller entstehen und vergehen lässt" und die "ihrerseits von einer vergänglichen Natur umgeben ist, deren Hinschwinden sich nur in einem langsameren Tempo vollzieht - und auch dies nur solange, als der Mensch die natürlichen Prozesse des Entstehens und Vergehens von Meeren, Kontinenten und Gebirgen sich selbst überlässt und nicht beschleunigend eingreift. Unvergänglichkeit jedenfalls ist aus der den Menschen umgebenden Welt wie aus der die Welt umgebenden Natur verschwunden." 
beings, humans and animals who perceive phenomena and as phenomena of almost infinite diversity have the ability "to see and be seen, hear and be heard, touch and be touched" (Grimm 1977: 19). These phenomena are not only subject to a natural necessity, but largely represent an end in themselves in their manifestations.

Elsewhere, Arendt draws an emotional picture of nature interacting with humans. In a review of the writer Adalbert Stifter's relationship to nature in his novels and stories, she describes it as unparalleled in its pure joy, wisdom, and beauty (2007). Arendt highlights the great beauty and "strangely innocent wisdom" of Stifter's work and his incomparable ability to unfold a narrative landscape painting of the mountains of Bohemia. For Stifter, nature is reality. The people who live there are part of the common cycle with nature. They have a home there and are not confronted by a foreign society. Arendt wrote that "Our sense of homelessness in society and of alienation in nature, whose laws we feel will function only as long as we leave it alone (as Kafka once put it), are constantly contradicted by Stifter" (2007: 113). The development of human nature in Stifter's works is the greatest good, according to Arendt, and trust is the highest virtue as a prerequisite for this development. The narrative "Rock Crystal" demonstrates this reality, beauty, and innocent wisdom. It tells the story about two children who get lost in a snowstorm in the mountains, and are rescued by the inhabitants of two villages; those inhabitants had been strangers until then.

Nature, the environment, technology, science, politics, and philosophy are inseparable in Arendt's view. As far-reaching as it is incomplete, her alternative suggests the creation of the world in the terms of inter-subjective worlds and the recovery of political action that subjects all human concerns to a deliberative process, including the contents of the sciences and their application. Her republican-cosmopolitan approaches lend weight to our perception of the environmental/earth crisis as a crisis of liberal and autocratic governments in our world(s). Against this background, technical solutions promoted as "geotechnology," such as the installation of reflective mirrors in space to minimize global warming, can be criticized not only in terms of feasibility, but above all as the continuation of an instrument-based creator mentality. Instead, we need to replace instrumental thinking with ecological thinking.

The critique of "globalization" has priority here, for instance, the ideas of Étienne Tassin, who describes international relations as world-destructive, domesticated, privatized, and consumed (2011: 15). According to Tassin, a globalized world in which the ecosystem of all living things, the cultural assets of all peoples, and the pluralist communities of political actors must be preserved and enabled calls for a corresponding threefold effort in the form of ecology, ecumenism, and cosmopolitanism in the interests of the environment, cultural assets, and the meta-national sphere.

Kerry Whiteside's above-mentioned argument that Arendt's remarks on the role of culture in ancient Athens and Rome deriving the preservation of "agri-culture" as an alternative to the exploitation and destruction of nature (1998) can also be found in the unity of town and country during the Renaissance, when culture was understood as the parallel preservation of culture, virtue, and landscape. Arendt's "worldly love of the Re- 
naissance" expressed itself in the landscape as the cultural topos of Dante, Petrarch, and Aeneas Sylvius before it was subjected to the new thinking of science and technology.

This worldly love of the Renaissance cannot be separated from the civic bourgeoisie's love of political freedom and equality. In 1338-1339, Ambrogio Lorenzetti frescoed the Room of the Nine in Siena's Palazzo Pubblico, depicting good and bad government, and their effect on the life of the city and the surrounding countryside. The prosperous bourgeoisie of the time was aware that the wealth of their city and the wisdom of their rulers could only be secured through peace, harmony, and equality under the rule of law, and the absence of selfish factions and damage to the common good (Skinner, 1998). These principles, known since Cicero, have shaped republicanism from that time even up to Arendt, and means more than the absence of war; they enable the development of the virtue that Montesquieu called the principle of the republic and includes the preservation of the land both for agriculture and as landscape. ${ }^{3}$

We also find equality under the rule of law in the constitution of our Western societies. Here, however, the republic and liberal democracy are not only structurally in permanent conflict with each other (indivisible or divided sovereignty, rule of the people or of law, rule of virtù or principle of virtue, etc.), but also represent two historically competing currents in the tradition of Rousseau/Marx, on the one hand, and Montesquieu/ Founding Fathers, on the other. The Principles of Corporate Social Responsibility, a UN initiative launched by Brazilian entrepreneurs in 2000 as the "Global Compact" to protect the interests of workers, customers, and the environment in a progressively globalized world, exemplifies the emergence of the rule of virtù at a time of active civil society in the style of Lorenzetti. Here, the principle of socially-responsible action is voluntarily adopted by numerous companies and social and political institutions around the world, transforming them into corporate citizens and members of civil society (Heuer, 2015a). This assumption of multiple responsibilities in the context of republicanism can bring about an effective shift from anthropocentrism to biocentrism, encouraging people to "build better relationships with nature itself and with other people. Such an approach should be based, firstly, on a logic of respect for nature, sufficiency and interdependence, shared responsibility and fairness for all in search of an ecologically balanced environment; and, secondly, on the ethics of a citizenship that thinks globally and locally at the same time and insists on transparency and accountability in all environmental matters" (Bollier, Weston, 2015: 418). ${ }^{4}$ Hence, the special report of the "German Advisory Council on Global Change" (WBGU) in 2014 bears the title of "Climate Protection as a World Citizen Movement" (WBGU, 2014).

3. We find no evidence here of a distinctly ecological policy of urban citizenship, but clearly a "knowledge of the indissoluble connection between city and country" as "a specific European cultural asset and thought" (Magel 2005: 39of.) needs to be revived.

4. Similarly, Jeremy Rifkin wrote that "Geopolitics has always been based on the assumption that the environment is a giant battleground - a war of all against all - where we each fight with one another to secure resources to ensure our individual survival. Biosphere politics, by contrast, is based on the idea that the Earth is a living organism made up of interdependent relationships and that we each survive by stewarding the larger communities of which we are a part" (2010: 615). 


\section{Humboldt - Nature as an Organism}

An outstanding example of these recommendations can be found in Alexander von Humboldt's ideas of nature and politics. Humboldt was filled with an irrepressible curiosity about nature, writing that "I have a longing for freedom and distant journeys." On his five-year, at-times-adventurous journey through the modern states of Venezuela, Cuba, Trinidad, Columbia, Ecuador, Peru, Mexico, and the United States, he collected numerous flowers and plants, noted down his observations of flora and fauna, soils, mountains, and climatic conditions. He took countless measurements of lengths, altitudes, and temperatures; he drew maps, but he was the opposite of the cool, technical surveyor portrayed by Daniel Kehlmann in the novel Measuring the World. Humboldt believed that "What speaks to our mind is beyond measurement" (Wulf, 2016: 102).

On the contrary, Humboldt found that nature spans the world like a single organism, and this is why he spoke of cosmos. He saw a natural whole, not a "dead aggregate" (Ibid.: 22). His realization that the vegetation in the earth's northern hemisphere resembled the upper mountain regions of the Andes served to prove that even regions and heights remote from each other were connected, an insight he used to establish a geography of plants.

In contrast to Francis Bacon, who regarded the world as created for man, or Descartes, who basically saw animals as robots (87), Humboldt witnessed countless interdependencies and established "how many things are linked to the existence of a single plant." He discovered the "principle of the key species ... which is of vital importance for an entire ecosystem" (105).

Humboldt himself would write that "The phrase physical description of the world that I use here is modelled on the long since commonly used physical description of the earth. The expansion of the content, the depiction of the natural whole from distant nebulae to the climatic spread of the organic tissues that color our cliffs, make the introduction of a new word necessary" (1845: 61). It is the cosmos in the Greek understanding of the world order that Humboldt was eager to permeate: he wrote that "My main impulse was the endeavor to conceive physical things in their general context and nature as a whole, moved and enlivened by inner forces, ... so that without serious inclination to the knowledge of the individual, all great and universal world-views can only be an airy vision" (Ibid.: vi). His attempt towards the end of his life to spread cosmos throughout numerous volumes of the same name was not fully crowned with success. "We are far from a time when it might be possible to concentrate all our sensuous views on the unity of the concept of nature" (Ibid.: 67).

It is this cosmos in the Greek understanding of the world order that Humboldt was keen to investigate. His idea of a multifaceted unity of nature also embraced people in their exchanges with nature. He was immensely interested in the social and political conditions of life, thus distinguishing him as a Republican, "a convinced Republican at the Prussian court" (Ette, 2007: 9). He describes the negative consequences of tree clearing and the subsequent soil erosion, and criticizes slavery and oppression. In his extensive 
studies on what is now Mexico, he detailed the social and political situation of the Indians and of African slaves, as well as the hatred that prevailed among the various social classes and seriously hindered the just economic development of the country. At the same time, Humboldt boasted that the Toltecs had "a far more perfect solar year than the Greeks and Romans" (2008: 164).

It was not only part of his ethos as a scientist but also of his humanist convictions that led him to determine "whoever experiences injustice, the grievances of the unfortunate should be brought to those who can alleviate them" (Wulf, 2016: 259). On his visit to the United States following his stay in Central and South America, Humboldt voiced his criticism of the slave economy to President Jefferson. He thanked Jefferson after his visit, saying "I have had the good fortune to see the first Magistrate of this great republic with the simplicity of a philosopher" (Casper, 2011: 258), a message that was followed by years of correspondence. Humboldt admired the newly-formed republic for not having taken the fatal course of the French Revolution. However, he was skeptical about the future of independence movements in Central and South America, since the strong cultural imprint of feudalism and the clergy coupled with lack of opportunity to cultivate republican practices bore the risk of ending in tyranny rather than a republic. Additionally, in 1854, Humboldt complained to Varnhagen about the decline of republicanism in the USA, writing that "the whole thing gives me the sad impression that freedom is simply a mechanism in the element of usefulness, refining little there to stimulate the spiritual and the comfortable, which is supposed to be the purpose of political freedom.... Hence indifference to slavery. But the United States is a Cartesian whirlwind, sweeping everything away, tediously levelling" (1999: 181f.).

\section{Cosmos and Republic as a Thinking Space}

Such a thinking space not only exists as a place for the exchange of views, but is characterized by Arendt's critique of the natural science disinterest in world and nature, and Humboldt's views of nature and the cosmos. Both differ completely from abstract, surveying, instrumental thinking. What is the object of our thinking? was the question Arendt asked herself, to which she replied: "Experience! Nothing else! And if we lose the ground of experience, then we get into all kinds of theory" (1996: 79).

For Humboldt, Hegel's approach to the world or even the cosmos was unbearable for its lack of vision. He would write that "A forest of ideas is certainly for me in that Hegel ... for a man who, like me, is banished to the ground like an insect and a difference of nature, an abstract assertion of purely false facts and views about America and the Indian world becomes liberty-robbing and frightening. I don't ignore anything great" (1999: 180).

Humboldt is the first scientist to produce scientific results in images; here, the pictorial representation is part of the cognitive process, not mere illustration. Since the perception of external nature and inner human nature not only takes place in concepts or in an unemotional outlook and unemotional thinking, but in the world of feelings as well, Humboldt's work is deliberately marked by sensual impressions that arise insolubly 
while observing nature. His Views of Nature is a "scientific book full of lyrical passages." For Humboldt, language was as important as content, and he did not allow a publisher to change a single syllable in order to preserve the 'euphony' of his sentences" (Wulf, 2016: 175). He emphasized "the combination of a literary and a purely scientific purpose, the desire to simultaneously engage the imagination and enrich life with ideas by multiplying knowledge" (Ette, 2001: 49).

In his book on what is now Mexico, he introduced his geographical account with an impressive description of a sandstorm, writing that "I have tried, always authentically describing, characterizing, even trying to be scientifically truthful, without entering the arid region of knowledge" (1860: 23)

Such a search for scientific knowledge prompted Humboldt's researcher, Ottmar Ette, to summarize Humboldt's method as trans-disciplinary rather than interdisciplinary (2006: 10).

Arendt's thoughts have been variously discussed in terms of her essayistic, openminded reasoning, which she referred to as "exercises in political thinking." Her description of semantic changes in concepts and of the ways of thinking in the period between antiquity and modernity provided the title Between Past and Future, for a collection of her essays. Her use of linguistic imagery and metaphors designate the new, irony, sharpness, and laughter, e.g., in the characterization of Eichmann, in the reduction of essentialist concepts to a minimum, which she called The Human Condition in order to display intersubjective phenomena. Her analysis of the use of poetry and literature in the reproduction of moods and experiences of political consequence typical of the time is presented in her books Rahel Varnhagen, The Origins of Totalitarianism, Men in Dark Times, and The Hidden Tradition; descriptions of the theatrical, atmospheric scenes (about Anton Schmidt, who had rescued persecuted Jews, in the Eichmann trial, and the recitation of Pasternak's poems by heart on the public when his work reappeared after a long period of being banned in the USSR and mentioned in her essay on the Hungarian Revolution) of imagination are a prerequisite of judgment, and the critique and redefinition of vita activa and vita contemplativa as joint action and thinking/judging in public (Hahn, 2005; Heins, 2007; Heuer, 2015b; Knott, 2011; Robaszkiewicz, 2017; Weißpflug, 2019; Zembylas, 2018). These arguments are closely linked to the emotional movements (writing with ira et studio, laughter, pure joy, wisdom and beauty, the "basic experience of abandonment", giving meaning and understanding to her feeling of amor mundi (Campillo 2019)). Nor should the transfer of Kantian aesthetic judgment to political judgement be interpreted as de-emotionalization, since "desinterested pleasure" underlies the process of judgment, and the appearance of the "who", as we saw in the reference to Portmann, has an aesthetic component (the beautiful gesture, or ugly behavior). Finally, Arendt's application of Salomo's "understanding heart" in her essay on "Understanding and Politics" (1994a: 322), which she used while investigating the conditions for judgment before embarking on her writings on Kant, shows that she was not seeking an abstract formula for judgment, but rather the possibility of understanding as a way to meaning. Meaningfulness through narratives and the perception of different perspectives and experiences requires 
the whole person, as the Enlightenment essayist and diplomat Melchior Grimm put it when he wrote that "The prerequisite for a distinct and mature taste is having a sharp mind, a sensitive soul and a righteous heart" (1977: 121).

What finally distinguishes this space of thought is a shared cosmopolitanism. In Arendt's work, its starting point is qualitatively interpersonal combined with an active plurality, which is followed in the second step by the relevant institutionalization of this plurality in the form of a federation (Heuer, 2016). Finally, in the third step, this plurality and federation requires an appropriate form of judgment, that is, the extended power of judgment adopted by Kant, the location of which is cosmopolitan. It presupposes that judges leave the exclusivity of the European or Western horizon and judge from a cosmopolitan location, which contradicts Hegel's pejorative critique of Chinese philosophy (Heuer, 2018).

Humboldt's view of the world is one that not only encompasses nature as a global organism, but, according to Ette, characterizes the world as a commonality of world trade, world history, world view, and world consciousness. What Alexander von Humboldt developed on the level of world knowledge was introduced by his brother, Wilhelm (with whom he constantly exchanged ideas) on the level of linguistic knowledge, so that it applies to both that "the dialogical principle is central not just to Humboldt's theory of language but also to his philosophical anthropology, and it has a direct political relevance. ... The diversity of languages and their comparative study is not just essential to our understanding of our own languages as well as those of others; it is intrinsic to the nature of language as such. Translation is thus a privileged route to cultural as well as linguistic communication" (Walker, 2017: 83).

Two things could be inferred from this cosmopolitan perspective. First, the preferred regional location is left but not abandoned, and is instead subjected to a critical assessment within the framework of many points of view. Second, a cosmopolitan attitude towards political action is adopted. Looking at international institutions from a regional or national perspective, (such as the UN Security Council), or from a perspective of international organizations (such as the courts of criminal justice), or rules (such as the Responsibility to Protect), and challenges (such as climate change and the extinction of species) is quite a different matter to looking at them from the variable and fluid standpoints in the world. Then, we find that these institutions are not merely promising approaches, but they are still far too weak as instruments when it comes to a much-needed future cosmopolitan policy where regional standpoints are not necessarily confined to their regions alone.

\section{Conclusion}

We can now conclude from what has been said that Arendt and Humboldt's self- and world-relationships seem radical in their strong rejection of any kind of instrumentalization of men and nature, and less so in their open or implicit criticism of the natural sciences. The preservation of nature is by no means absent in Arendt's statement that the 
meaning of politics is freedom, and that the realization of human plurality is the basis of politics and freedom. Neither is it missing in Humboldt's statement that the unity of man and nature includes a republican respect for mankind. Both perspectives exclude the exploitation of man and nature in open or hidden forms like cheap promises, or technical solutions such as solar sails in space to prevent the global rise in temperature.

It is no coincidence that Arendt and Humboldt have a peculiar way of writing that cannot be separated from the perspective of their thinking. The question that cannot be further examined here is the extent to which republicanism that is oriented towards sustainability and Arendtian action as an end in itself finds its expression in its own way of thinking and writing. Weaving the threads of Humboldt and Arendt further would not only bring cosmos and republic together, but also Grimm's unity of judgment, feeling, and prudence in a way that overcomes opposition and disciplinary boundaries, nature and culture, reason and feeling, and science and aesthetics. This means that cosmos and republic could trigger a common environmental philosophy and environmental aesthetic that goes beyond a natural philosophy, and natural aesthetics confined to external nature. $^{5}$

Finally, we have seen that cosmopolitanism in the face of global problems becomes an indispensable place of thought and politics at which one arrives from nature with Humboldt, and from human plurality and Kant's enlarged mentality of judgment with Arendt. All of this opens up avenues for further reflections from a republican-biocentric perspective.

\section{References}

Arendt H. (1958) The Human Condition, Chicago: University of Chicago Press.

Arendt H. (1977) The Life of the Mind, New York: Harcourt, Brace Co.

Arendt H. (1987) Collective Responsibility. Amor Mundi: Explorations in the Faith and Thought of Hannah Arendt (ed. J. S. Bernauer), Berlin: Springer, pp. 43-50.

Arendt H. (1994a) Understanding and Politics. Essays in Understanding 1930-1954, New York: Schocken, pp. 307-327.

Arendt H. (1994b) Natur und Geschichte. Zwischen Vergangenheit und Zukunft: Übungen im politischen Denken I, München: Piper, pp. 54-80.

Arendt H. (1996) Ich will verstehen: Selbstauskünfte zu Leben und Werk, München: Piper. Arendt H. (2002) Denktagebuch, München: Piper.

Arendt H. (2006a) The Concept of History: Ancient and Modern. Between Past and Future: Eight Exercises in Political Thought, New York: Penguin, pp. 17-40.

Arendt H. (2006b) The Conquest of Space and the Stature of Man. Between Past and Future: Eight Exercises in Political Thought, New York: Penguin, pp. 265-28o.

Arendt H. (2007) Great Friend of Reality: Adalbert Stifter. Reflections on Literature and Culture, Stanford: Stanford University Press, pp. 110-114.

5. For further reflections, see Böhme, 2019: 41. 
Böhme G. (2019) Leib: Die Natur, die wir selbst sind, Berlin: Suhrkamp.

Bollier D., Weston B. H. (2015) Das Menschenrecht auf eine saubere Umwelt und die Renaissance der Commons. Commons: Für eine neue Politik jenseits von Markt und Staat (ed. S. Helfrich), Bielefeld: Transcript, pp. 416-425.

Campillo A. (2019) El concepto de amor en Arendt, Madrid: Abada.

Cannavò P. (2016) Environmental Political Theory and Republicanism. The Oxford Handbook of Environmental Political Theory (eds. T. Gabrielson, Ch. Hall, J. M. Meyer, D. Schlosberg), Oxford: Oxford University Press, pp. 72-88.

Casper G. (2011) A Young Man from "Ultima Thule" Visits Jefferson: Alexander von Humboldt in Philadelphia and Washington. Proceedings of the American Philosophical Society, vol. 155, no 3, pp. 247-262.

Chapman A. (2007) The Ways That Nature Matters: The World and the Earth in the Thought of Hannah Arendt. Environmental Values, vol. 16, no 4, pp. 433-445.

Donohoe J. (2017) Edmund Husserl, Hannah Arendt and a Phenomenology of Nature. Phenomenology and the Primacy of the Political: Essays in Honor of Jacques Taminiaux (eds. V. M. Fóti, P. Kontos), Cham: Springer, pp. 175-188.

Ette O. (2001) Eine "Gemütsverfassung moralischer Unruhe" - "Humboldtian Writing": Alexander von Humboldt und das Schreiben in der Moderne. Alexander von Humboldt: Aufbruch in die Moderne (eds. O. Ette, U. Hermanns, B. M. Scherer, Ch. Suckow), Berlin: De Gruyter, pp. 33-56.

Ette O. (2006) Unterwegs zu einer Weltwissenschaft? Alexander von Humboldts Weltbegriffe und die transregionalen Studien. HiN: Alexander von Humboldt im Netz, vol. 7, no 13, pp. 34-55.

Ette O. (2007) Das Mobile des Wissens: Alexander von Humboldts Foren der Kulturen und das Humboldt-Forum. Zukunftsmodell Humboldt, Bonn: Bundeszentrale für politische Bildung.

Grimm M. (1977) Paris zündet die Lichter an. Literarische Korrespondenz, Leipzig: Dieterich'sche Verlagsbuchhandlung.

Hahn B. (2005) Hannah Arendt: Leidenschaften, Menschen und Bücher, Berlin: Berlin Verlag.

Hargis J. 2016) Hannah Arendt's Turn to the Self and Environmental Responses to Climate Change Paralysis. Environmental Politics, vol. 25, no 3, pp. 475-493.

Heins V. M. (2007) Reasons of the Heart: Weber and Arendt on Emotion in Politics. The European Legacy, vol. 12, no 6, pp. 715-728.

Heuer W. (2015a) El poder de los insensatos: libertad y responsabilidad para una economía sustentable. Discursos políticos, identidades y nuevos paradigmas de gobernanza en América Latina (ed. Á. Sierra González), Barcelona: Laertes, pp. 81-111.

Heuer W. (2015b) Horror and Laughter: At the Limits of Political Science. Violence, Art, and Politics (ed. Z. Kurelic), Zagreb: Politicka Misao, pp. 62-75.

Heuer W. (2016) Föderationen: Hannah Arendts politische Grammatik des Gründens, Glückstadt: J. J. Augustin. 
Heuer W. (2018) As crises contemporânes e a perspectiva cosmopolita. Paper presented at I Colóquio Internacional Hannah Arendt: Totalitarismo, Subjetividade e Responsabilidade (Rio de Janeiro).

Humboldt A. v. (1845) Kosmos, Bd. 1: Entwurf einer physikalischen Weltbeschreibung, Stuttgart: J. G. Cottascher.

Humboldt A. v. (1860) Briefe von Alexander von Humboldt an Varnhagen von Ense aus den Jahren 1827 bis 1858: Nebst Auszügen aus Varnhagen's Tagebüchern und Briefen von Varnhagen und Anderen an Humboldt, Leipzig: F. A. Brockhaus.

Humboldt A. v. (1999) Über die Freiheit des Menschen: Auf der Suche nach Wahrheit, Frankfurt am Main: Insel.

Humboldt A. v. (2008) Versuch über den politischen Zustand des Königreichs Neu-Spanien, Darmstadt: Wissenschaftliche Buchgesellschaft.

Knott M. L. (2011) Verlernen: Denkwege bei Hannah Arendt, Berlin: Matthes \& Seitz.

Magel H. (2005) Ländlicher Raum Wohin? Plädoyer für ein nachhaltiges Landmanagement und eine aktive Bürgergesellschaft. Allgemeine Vermessungsnachrichten (AVN), no 11-12, pp. 390-391.

Ott P. (2009) World and Earth: Hannah Arendt and the Human Relationship to Nature. Ethics, Place and Environment, vol. 12, no 1, pp. 1-16.

Rifkin R. (2010) The Empathic Civilization: The Race to Global Consciousness in a World of Crisis, New York: TarcherPerigee.

Robaszkiewicz M. (2017) Übungen im politischen Denken: Hannah Arendts Schriften als Einleitung der politischen Praxis, Wiesbaden: Springer.

Skinner Q. (1986) Ambrogio Lorenzetti: The Artist as Political Philosopher. Proceedings of the British Academy, vol. 72, pp. 1-56.

Tassin É. (2011) De la domination totale à la domination globale: perspectives arendtiennes sur la mondialisation d'un point de vue cosmopolitique. Hannah Arendt: le totalitarisme et la banalité du mal (ed. A. Herzog), Paris: PUF pp. 147-169.

Walker J. (2017) Wilhelm von Humboldt and Dialogical Thinking, Forum for Modern Language Studies, January, vol. 53, no 1, pp. 83-94.

WBGU (2014) World Citizens Movement and Climate Protection, Berlin: AZ Druck und Datentechnik.

Weißpflug M. (2019) Die Kunst, politisch zu denken, Berlin: Matthes \& Seitz.

Whiteside K. H. (1998) Worldliness and Respect for Nature: An Ecological Application of Hannah Arendt's Conception of Culture. Environmental Values, vol. 7, no 1, pp. 25-40.

Wulf A. (2016) Alexander von Humboldt und die Erfindung der Natur, München: C. Bertelsmann.

Yaqoob W. (2014) The Archimedean Point: Science and Technology in the Thought of Hannah Arendt, 1951-1963. Journal of European Studies, vol. 44, no 3, pp. 199-224.

Zembylas M. (2018) Hannah Arendt's Political Thinking on Emotions and Education: Implications for Democratic Education. Discourse: Studies in the Cultural Politics of Education. Available at: https://www.tandfonline.com/doi/full/10.1080/01596306.2018 .1508423 (accessed 23 October 2019). 


\title{
Космос и республика: скрытый диалог между Ханной Арендт и Александром фон Гумбольдтом
}

\author{
Вольфганг Хойер \\ Приват-доцент, Институт политических наук им. Отто Зура, Свободный университет Берлина \\ Главный редактор журнала HannahArendt.net \\ Адрес: Ihnestraße 21, Berlin, Germany 14195 \\ E-mail: wolfgang.heuer@gmx.de
}

В рамках настоящей статьи объединяются две теоретические концепции: республиканизм Ханны Арендт и космополитизм Александра фон Гумбольдта. Оба способа мышления рассматриваются как альтернативные концепции республиканско-биоцентрического взгляда на современный кризис в области политики и экологии. Критика Арендт современного естествознания и связанного с ним отчуждения от Земли, до сих пор характеризующего нынешнее отношение к природе, будет представлена первой. Эта критика тесно связана с тезисом Арендт об утрате мира, т.е. утрате межличностной плюралистической сферы. В качестве альтернативы обеим формам утраты, Арендт развивает концепцию независимой политической сферы, основанной на межличностных отношениях, гармонии с природой, политике диалога и консенсуса. В то время как Арендт подходит к природе, исходя из кантовского определения отношения к себе и миру, основываясь на своем понимании экологически ответственной политики, Гумбольдт идет противоположным путем — от уважения к природе как независимого организма к республиканскому пониманию политики, отвергающему, как и Арендт, эксплуатацию людей и природы. И Арендт, и Гумбольдт придерживались традиции Просвещения, в которой помимо феноменологии, саморефлексии, ценностей человеческого достоинства и прав человека, единства понимания и чувства, также содержится космополитизм свободы передвижения в качестве действующих и выносящих суждения граждан.

Ключевые слова: Ханна Арендт, Александр фон Гумбольдт, республиканизм, космос, антропоцен, природа, процесс, космополитизм 